\title{
Erratum to: Hydraulic regime-based zonation scheme of the Curonian Lagoon
}

\author{
Christian Ferrarin - Arturas Razinkovas • \\ Saulius Gulbinskas • Georg Umgiesser • \\ Lina Bliūdžiutè
}

Published online: 30 June 2010

(C) Springer Science+Business Media B.V. 2010

\section{Erratum to: Hydrobiologia \\ DOI 10.1007/s10750-008-9454-5}

The first and family names of the authors were transposed in the original article. The correct names are given here. We apologise to the authors for this error. doi:10.1007/s10750-008-9454-5.

C. Ferrarin $(\bowtie) \cdot$ G. Umgiesser Institute of Marine Science, ISMAR-CNR, Castello 1364/A, 30122 Venezia, Italy

e-mail: c.ferrarin@ismar.cnr.it

A. Razinkovas · S. Gulbinskas · L. Bliūdžiutè Coastal Research and Planning Institute,

Klaipeda University, Klaipeda, Lithuania 